\title{
The Language(s) of Ecological Restoration
}

T am not a religious person, but my therapist is. Recently, he sent me a copy of his book How to Be a Christian and Still Be Sane (B. Beverley, 2007, iUniverse, Inc., New York), in which he uses excerpts from the Bible to show how, in his opinion, much of modern Christianity has strayed away from the original tenants of the faith, which include loving thy neighbor, not judging others, and staying grounded in the laws of nature. I was raised in a Methodist church, one of my brothers-in-law is a Baptist minister, and I have been married to two women, one from a Protestant background and the other a Catholic background. I even took a religious studies course in college. So I am familiar enough with the Christian faith to understand his point, beautifully illustrated through a series of biblical quotations. But I can also see the flip side of the coin, where others might use excerpts from the Bible (or other religious texts) in a distorted way to further a negative or destructive agenda. In this world of constant religious and secular strife, it makes you wonder how we can possibly communicate with each other in a meaningful and accurate way in our own language, much less among two or more languages.

When the Society for Ecological Restoration International was born more than 20 years ago the language of the society was English_period. We had a single "international representative," Ariel Lugo from Puerto Rico, who probably speaks English better than I do. In the early days the remainder of the board members came from the United States and Canada. It wasn't until the mid-nineties that we had a board member from outside of North America and the Caribbean, and that was Mike Oxford from the United Kingdom, followed in the late nineties by Noel Corkery from Australia. In 2000, Carolina Murcia became the first board member from South America, joining at the first SERI conference held outside of North America in Liverpool, England (and organized by Mike Oxford). Carolina also has strong English language skills, having received her PhD from the University of Florida. Despite the jump across the pond, we had only a single board member from Europe until then-acting European representative Jim Harris (United Kingdom) was joined by board member at-large Rudy van Diggelen (the Netherlands) in 2002. The

Ecological Restoration Vol. 27, No. 1, 2009

ISSN 1522-4740 E-ISSN 1543-4079

(C2009 by the Board of Regents of the University of Wisconsin System.
Dutch have a strong national commitment to developing English language skills among the populace, and Rudy also has no problem reading, writing, and speaking in English. Our first international conference held in a country in which English is not a first language wasn't until 2005 in Zaragoza, Spain. Although it would have been wonderful to have some simultaneous translation between English and Spanish, economics dictated that the official language of the conference be English. It was at the board elections in the summer of 2007 that true international representation to the SERI board was finally achieved. While Americans were still the most numerous (9), we were joined by colleagues from Canada (3), Europe (3), South America (2), Africa, and Australia. For five of 19 board members, English was not their first language. Another first occurred in 2008 during a board teleconference, when a board member had someone translate for them during the meeting. This was repeated at our face-to-face board meeting in November in Tampa, Florida, where SER Project Director Sasha Alexander translated Portuguese into English on behalf of Maurice Balensiefer, from Brazil.

The IUCN has three official languages (English, Spanish, and French) and the United Nations has six (add Russian, Chinese, and Arabic), but in the side meetings and hallways it is English that generally prevails. It is difficult for those without strong English skills to fully participate. This is a problem. There are literally thousands of languages around the globe, and translating even just six languages simultaneously requires at least 15 translators, who must be relieved by other translators after a short while to avoid fatigue. It is enormously expensive.

Like agriculture, forestry, fishing, social work, and other place-based activities, ecological restoration ultimately must be implemented and embraced by local populations speaking local languages. This is also true of academia in many parts of the world where non-English languages rule. More and more university-trained people speak English, but we English-first speakers are deluding ourselves if we think that we can communicate worldwide about restoration without finding a way to communicate with people who do not speak or read English, or do so with difficulty.

In acknowledgment of this fact, SERI has begun to translate our foundation and policy documents into other languages. For instance, SERI's Primer on Ecological Restoration has been translated into Spanish, French, Italian, and Mandarin Chinese. In advance of the World Conservation 
Congress in Barcelona, Spain, we printed the SERI Primer in Spanish, and have begun to distribute it in Mexico and elsewhere. We have also started to populate our Global Restoration Network website (www.globalrestorationnetwork.org) with case studies in Spanish. But we have a long, long way to go.

A recent restoration ecology conference in Brazil drew about 800 people. The official language of the meeting was Portuguese. Yet in the Brazilian Amazon, where there are dozens, if not hundreds, of living indigenous languages, expanding our linguistic scope to include all the major world languages would not be enough. In a perfect world we would be able to communicate with people speaking indigenous languages in areas where restoration is occurring. This is not only because we need to communicate with all stakeholders when doing restoration, but also because indigenous people and their languages are part of the fiber of the ecosystems in which they live.

Knowing that the bible is the most translated book in the world only unsettles my mind more. If Christians living in the same country and speaking the same language can interpret the same verses in so many different ways, how are we to speak the languages of ecological restoration with more consistency, while having the wisdom to understand that the nuances of language are often expressions of local knowledge and experience? Somehow we must do better than other disciplines have done. The world depends on it.

George Gann

Chair, Society for Ecological Restoration International 